\title{
THE COMPOSITION OF SINGAPOREAN SHOPPING CENTRES
}

Published in:

The International Review of Retail, Distribution and Consumer Research

Vol. 22, No. 3, July 2012, 261-275

Keri Davies

Corresponding Author:

Dr Keri Davies

Institute for Retail Studies

University of Stirling

Stirling

Scotland FK9 4LA

United Kingdom

Tel: $\quad 01786467408$

Email: $\quad$ b.k.davies@stir.ac.uk

Length of paper: 8716 words 


\title{
THE COMPOSITION OF SINGAPOREAN SHOPPING CENTRES
}

\begin{abstract}
With its growing population but limited supply of land, Singapore has seen a huge increase in the number and size of shopping centres in recent years. This growth has led to two rather contradictory outcomes - more choice for retailers in their efforts to reach customers but also claims that too many of the centres contain the same types of retailers and contain no real differentiation in their offerings. This paper looks at this trend and reports on a survey of the composition of store types in a wide range of Singaporean shopping centres to consider whether or not these views are based on a full picture of the roles played by these shopping centres.
\end{abstract}

\section{Introduction}

In recent years the retail economy of Singapore has come to rely increasingly on enclosed shopping centres or malls. The demand for new retail space has been high, partly because of the growing population and partly because of the demand from consumers for better, airconditioned shopping environments as their incomes have increased and as they have gained experience of retailing in other parts of the world. Critics, however, have suggested that too many of the centres serve the same functions or contain the same retail brands and thus tend to look alike.

The purpose of this paper is to test this assertion by considering the similarity of shopping centres in Singapore using data collected by a survey of all of the uses and store types contained within a sample of those centres. This study further considers impact of the form of shopping centre ownership or management on the uses that exist in each centre.

The next section provides a brief description of the development of the retail structure of Singapore to help to explain why some of these different forms of management have evolved. It is proposed that shopping centres under certain types of management will be more similar 
in terms of the types of stores that they contain than centres under other forms of management, and that the form of management and the location of the centres have also affected the type of retail brands that will locate in those centres.

\section{The Evolution of Singapore's Retail Structure}

Singapore's retail structure has evolved over the past sixty years reflecting both commercial pressures and significant state intervention and central planning. Before 1960, retail facilities were concentrated in the Central Business District, including Orchard Road, and several ethnic centres in the central area. The public housing programmes initiated under the auspices of the Housing and Development Board (HDB) led to the development of large suburban housing estates. These estates were provided with a planned hierarchy of retail and service facilities through HDB town and neighbourhood centres (Yeung and Yeh, 1971).

At roughly the same time, urban renewal and market forces led to the rapid development of planned shopping centres in the central area by private developers. These enhanced the importance of Orchard Road and Chinatown as shopping districts for both Singaporeans and tourists. By the mid-1980s there were seventy planned shopping centres in Singapore, 46 in the Central Area and 24 in suburban locations, with more under development (Sim, 1984: p.28). There was however a very strong bias towards local or Singaporean retailers in these centres. In a study of eight planned shopping centres, Sim found that 94.2 per cent of tenants were Singaporean, against 5.8 per cent of foreigners. There were some large foreign retailers present in Singapore at this time, notably the Japanese department stores Isetan, Daimaru and Yaohan, and the French Le Printemps and Galeries Lafayette. However, the bulk of foreign retailers in Sim's sample were independent retailers from India, Indonesia and Malaysia, most of whom were to be found trading in just four sectors: textiles and tailoring, arts and crafts, antiques and jewellery/ watches (Sim, 1984: p.44). She also found some evidence of 
specialization based on either goods or ethnicity where groups of traders had moved into these new centres en masse.

By the early 1990s the retail structure established in the 1960s was beginning to fail. With a growing population and a strong economy there was a demand for better shopping facilities and a recognition that there was too much of an emphasis on the Central Area. Neither the existing retailers nor the transport infrastructure could cope with the influx of Singaporeans and tourists onto Orchard Road or Chinatown at peak periods. There was also a growing belief that the design of many of the existing shopping centres, both HDB and privatelyowned centres, no longer matched the needs of modern retailers and consumers (Foley, 1994). The reaction of the Singapore government was to introduce the Retail Sector Development Plan (RSDP) in 1992 alongside a scheme to sell HDB shops to tenants wherever possible (Sim and Choo, 1993). Taken together these actions have had a major effect leading to development of a number of major regional centres (Tampines, Woodlands and Jurong), along with a number of sub-regional centres (Davies, 1993; Sim and Goh, 1998; Sim, 1999; Ibrahim and Peng, 2005). These provide for a much wider range of the needs of local suburban residents, making it easier for them to shop locally as well as relieving the pressure on the Central Area. Even when only partially developed, Tampines was assessed to be keeping trade within the eastern end of Singapore which had previously gone to the Central Areas but it was also having an adverse effect on neighbourhood centres (Sim and Goh, 1998).

Almost as significant has been the growth of new private shopping centres alongside the Mass Rapid Transit (MRT) network Nearly every new MRT station now sits either over or alongside a centre which provides for many of the day-to-day needs of local residents (Fatt, 2001; Sim et al, 2002). 
There are two main implications of these changes that concern this study. First, the changes have created a rich mix of uses and market positions (Table 1). In part, this is because the new shopping centres developed since 1992 still sit alongside many of the planned shopping centres developed since the early 1970s. And, second, whilst the newer centres are under a more active form of management interested in the development of a planned market position, many of the older centres are either under multiple or 'strata' ownership or do not really aim to project a coherent image.

[Table 1 about here]

Many of the latter have survived because shopping centres in Singapore have to enclose the 'fringe' activities that would normally be found on the more traditional shopping streets in countries such as the United Kingdom or United States. Even shopping centres along the premier shopping area of Orchard Road may host shoe repairers, hairdressers, banks, maid services, travel agents, money remittance agents, and fortune tellers to name but a few.

But even where the real estate sector has had a major influence on the form and letting policies of shopping centres (White and Gray, 1996), and despite the efforts of some of the new Real Estate Investment Trusts (REITs) in recent years (Whiting, 2007), shopping centre managers have been criticised for creating a perceived uniformity in terms of their retail offer. Henderson et al (2011) note that few tourists venture outside the heart of the city for shopping, despite being urged to do so in several guides. "Complexes can resemble each other, despite management efforts to forge distinct identities, and the ubiquitous shopping environments of homogenised ultramodern air-conditioned spaces with global brands are easily replicated. They may also be of reduced appeal to visitors seeking difference in terms of atmosphere and products" (op cit, p.41).

It is in this atmosphere that retailers have to make decisions regarding which shopping centres they would wish to enter and shopping centre managers have to decide on the mix of 
retail types that they wish to present to customers. In part this will be decided by their location and customer base, but it will also relate to the form of management of each centre. We can suggest that shopping centres with the same form of management will be more similar in the types of stores that they contain than centres with other forms of management. The impetus of the Retail Sector Development Plan has spread modern shopping centres across the whole island. The older shopping centres, which tend to be managed less actively, are concentrated in and around the Central Area, whereas the newer shopping centres are to be found primarily on Orchard Road and in suburban areas. We might expect shopping centres to reflect the customer base that is available in each location (West, 1992).

Singapore has been attractive to retail brands from other parts of the world because of the growing consumer spending power of its population and because of the large number of tourists who spend some time on the island. These brands have to make decisions about where they wish to locate and about the type of shopping centre they would prefer. It is likely that international brands will prefer to open in Managed shopping centres and to locate on Orchard Road or in the central area rather than suburban areas.

\section{Methodology and Data Collection}

Whilst there was published data on some of the larger shopping centres, especially those owned by a REIT, there was no easily available record covering a larger number of centres. Following on from the discussion above, the aim of the survey work was to look at as wide a range of shopping centres as possible and to catalogue the whole spectrum of uses of each centre, not just the retail outlets.

Accordingly, visits were made to over 100 shopping centres in Singapore in a five-week period in 2009. The aim was to capture data from all of the centres trading on Orchard Road, 
all of the centres attached to MRT stations and then the centres operating in the Downtown area working as far outwards as time would allow. The survey pre-dated the opening of a number of centres such as Ion Orchard and 313 Somerset; POMO (formerly the Paradiz Centre) was surveyed although it was not fully open but some centres, such as those in the Tekka area, were discounted because of the scale of redevelopment that was taking place at the time. In total, data was collected for 104 centres.

The data collection process consisted of recording all of the accessible units within the solum, or main trading area, of each of the centres visited, but excluding any clearly separate part of the development. For example, one centre had six trading floors (including 2 basement floors) and an associated office block above the centre. Whilst the office block was excluded from the survey, any offices, non-retail uses and empty units located on those six trading floors were included, even though there were no 'standard' retailers on one floor. Prior to the survey a detailed break-down of possible product categories was prepared but this was amended during the initial stages of the survey to capture as detailed a view of each centre as possible. By the end of the survey, data was being recorded for a total of 82 product areas which were grouped into 30 categories (Table 2). The larger categories are used for the similarity analyses below.

In addition to recording the number of units in each product area, the presence of chain stores was also noted. These retail brands were allocated to one of the product categories, and were categorised as either International, Regional or Singaporean. Technically, all nonSingaporean brands should be International but the aim here was to distinguish between brands that are more geographically (and possibly psychically) distant compared to those originating within the Asia Pacific region. As a result, the list of International brands included those from Europe, North and South America and Africa, whereas the Regional list included countries such as Australia, China, Japan, South Korea, Malaysia and Thailand. The 
list of Singaporean retail brands also had to be amended as the survey progressed and, as a consequence, it may under-estimate the size of some of the smaller chains.

[Table 2 about here]

Whilst the ownership and management style of a number of the centres was readily available, particularly for those managed by a REIT, it was much more difficult for the older centres in the Downtown area. Where the information was not available from secondary sources, an informed decision was made following the visit to each centre. A simple threefold distinction was made: first, was the image of the centre and of the mix of stores in the centre being actively managed? Where this was not felt to be the case, a centre has been recorded as 'Strata' to represent the piecemeal approach to the mix and its limited ability to attract certain types of retailer.

For the stores with a more active management style, they were also split according to whether or not they were 'attached' to an MRT station. The rationale for this decision was to explore whether or not the presence or absence of the MRT has influenced the development of a centre. It was not enough for a centre to be 'close' to an MRT station; the MRT had to be connected sufficiently strongly to the centre for it to have influenced the development of the centre. To allow for the development of Ion Orchard and 313 Somerset, none of the existing centres in those locations were deemed to be MRT centres. The distribution of the 104 centres across these 3 categories of Managed, MRT and Strata was 42, 29 and 33 respectively. Finally, the centres were allocated to one of the five planning areas used by the Singapore Competition Commission (2008) (Credit Suisse, 2011). These were:

- Orchard Road - the main shopping area on the Island. This area has seen a number of new centres and older and less well-located centres have faced vacancy risks and downward pressure on rents. (34 centres) 
- Downtown Core - a large established shopping area that includes a range of older centres, e.g. Peninsula Plaza, Marina Square or Raffles City, along with later developments such as Suntec City and Millenia Walk. (10 centres)

- $\quad$ Rest of the Central Area - areas such as Outram, Newton and River Valley. (27 centres)

- Fringe Area - an area that includes a number of older shopping centres in the HDB town centres, such as Bukit Merah, Queenstown, Bishan, Novena and Toa Payoh. (10 centres)

- $O C R$ - centres outside the Central Area, which includes all of the centres established in the Regional Centres. (23 centres)

There were a number of limitations to the study. It was designed to be easy to administer and to use readily available public information. It deals with store type only; as it could not capture information about the relative size of the units in each centre or category (either by floorspace or turnover); initial efforts to record units against a 3 or 4 point size scale were abandoned as too difficult. Also, the Singaporean retailers were recorded as chain stores if either they were already known brand names or if the same name was found in more than one centre. Since only a sample of known names was recorded, it is possible that some small chains were missed. Also, a chain with, for example, units in several unplanned locations but just one unit in the surveyed centres may have been overlooked in this process.

\section{Findings}

The survey found almost 13,000 units in the 104 centres surveyed. Of these, almost 3,000 belonged to retail chains and just over 7,000 to independent (single store) retailers; there were nearly 2,500 units in non-retail uses and a further 424 vacant units. Table 3 shows how the units were distributed across the three management styles. As was expected from the 
discussion above, there was an almost universal preference among retail chains for managed centres. The Strata centres were much more likely to house independent retailers and nonretail uses, whilst the MRT centres had the lowest number of non-retail units.

[Table 3 about here]

Table 4 shows the distribution of the units by planning region. Whilst it might have been expected that local chains and independent retailers would be most commonly found in the OCR region, it was slightly surprising to find that this region also had a high number of International and Regional brands. The 33 OCR centres had as many of these brands as the 44 centres in the Orchard and Downtown Core regions combined.

[Table 4 about here]

\section{Similarity of Shopping Centres by Management Type}

In order to examine the similarity of shopping centres in terms of the store types that they contain, this study uses some of the measures put forward by West (1992) in his work on shopping centre similarity in Canada. The main measure of similarity used here is as follows:

\section{$S_{i j}=$ number of store types in centre $i$ that are present in centre $j$} average number of store types in $\mathrm{i}$ and $\mathrm{j}$

Note that $0 \leq \mathrm{S}_{\mathrm{ij}} \leq 1$ and $\mathrm{S}_{\mathrm{ij}}$ can equal one even if centres $i$ and $j$ have different numbers of stores.

Table 5 presents the mean and standard deviation of $\mathrm{S}_{\mathrm{ij}}$ for different sets of shopping centres, where the higher the average, the more similar are the centres being analysed. The group of MRT centres is far more similar than either the Managed or the Strata centres, with a very low standard deviation. The last three rows look at the level of similarity between the different groups of centres and yield mixed results. The average similarity between MRT centres and 
both of the other types of centre is higher than that between the Managed and Strata centres. There appears to be something about the MRT centres that makes them stand out; we will return to this below.

[Table 5 about here]

If we turn to the location of the centres, Table 6 reports the similarity figures for each of the five planning areas. This shows that shopping centres on Orchard Road and in the Rest of the Central Area are clearly less similar than those in the other locations. The high scores for the Fringe and OCR locations will relate in the main to the large number of MRT centres in these locations but this does not really explain the score for the Downtown Core.

[Table 6 about here]

The factor that joins Tables 5 and 6 is the very focussed nature of the shopping centres that have been developed in recent years, and particularly the MRT centres. Whilst there are some store types that are to be found in most all MRT centres, such as a florist, , keycutting, laundry and photo processing, these can also be found almost as often in Managed and Strata centres. Rather, as is shown by the low standard deviation in Table 5, it is the store types that are missing from the MRT centres but are found in the others that make the difference.

Whilst some store types such as bars \& clubs, internet gaming and tattoo parlours are mainly restricted to the Strata centres, even Managed centres on Orchard Road contain beauty salons, education facilities, medical surgeries and maid services.

\section{Similarity of Shopping Centres by Retail Brands}

Table 3 reported that a large number of international and regional brands could be found in all of the management types and locations. If we look at just retail brands, Table 7 compares brand origin across a range of product areas. International brands were concentrated in some of the larger product areas such as clothing, cosmetics, health, restaurants and shoes which are 
found across all of the locations in Singapore. But whereas luxury clothing brands might have just one or two units in shopping centres on Orchard Road, virtually every MRT centre has a McDonalds or Burger King, a Starbucks, a Body Shop or a GNC unit. Opening up the suburban centres to foreign retailers since the 1990s has brought a wide range of 'everyday' international brands to the OCR region, whilst leaving most of the luxury brands in the Orchard and Downtown Core regions.

[Table 7 about here]

If we look at the similarity matrix for retail brand origin by type of management (Table 8) we find that the MRT centres are reported as being significantly more similar across all four brand groups than the other two types of centre. For chain retailers, the Managed centres and MRT centres are also more similar across the International, Regional and Singaporean chain categories than they are when compared with the Strata centres. But, just to reinforce the argument that these centres are not just about chain retailers, all of the Management types show much higher levels of similarity between centres in terms of Independent retailers. [Table 8 about here]

And, finally, Table 9 looks at Retail Brand Origin by Management type and Location. As would be expected from Table 9, the MRT centres show high similarity levels throughout. Managed centres have relatively low levels in most categories except for the Independent sector. They are most similar in the Downtown Core locations and for International and Regional Brands in the OCR. Strata centres are weak throughout in International and Regional brands and most similar in Independents in all locations (except OCR where there were no recorded Strata centres) and in Singaporeans chains in Fringe locations.

[Table 9 about here] 


\section{Discussion}

This has been a fairly simple survey, although replicated across a wide range of shopping centres throughout Singapore. It was expected that shopping centres with a strong management and image would show higher levels of similarity because of the need to compete for customers. This was found to be true for MRT centres but not for other Managed centres. There are two possible reasons for this disparity which would merit further investigation. One possibility relates to an outcome of active management. If shopping centre managers have noted the complaints about 'clone malls' or 'all shopping centres looking the same', then this lack of similarity may reflect their activities in shuffling the types of store that they will allow into their centres. This would be particularly apposite for the more experientially oriented malls on Orchard Road. The MRT centres, on the other hand, are based more on convenience and locations close to consumers and so they are perfectly content to duplicate many of the most common store types.

Another possibility is that the survey reminds us of what most Singaporeans already know. Shopping centres in Singapore are seldom just about the retail mix, even if it is one of the most important aspects of each centre. They are also 'living spaces' which have to accommodate most, if not all, of the retail and related service needs of the people of Singapore, including those who work in the offices often to be found above many shopping centres. The lack of similarity may therefore relate less to the core store types and more to the desire to offer a wide range of facilities to a wide-ranging community. It is not unexpected therefore to find hairdressers in upmarket centres on Orchard Road or fortune tellers in MRT centres.

The Managed and MRT centres may succeed in retail terms but it is just possible that they actually need the Strata centres to help with their success. (Given the size and tangled 
ownership structures of many Strata centres it is unlikely that REITs or property firms could acquire all of the other centres in any case.)

More importantly, however, the Strata centres in particular offer an outlet for units that might not be acceptable under normal circumstances in many of the other centres. This has already been noted in terms of bars and clubs; similarly, almost all of the adult/ sex shops, internet gaming and tattoo parlours are to be found in Strata centres. And these centres also offer a lower-cost incubator environment to allow retail entrepreneurs and new retail formats a chance to experiment and to gain a foothold before moving into busier, higher-rent premises. The survey helps to emphasise the inter-related nature of much of this retail system; lacking other outlets or new forms of retail space, older shopping centres have been adopted as places where new ideas can emerge and a wider range of retail and social relationships can be undertaken. It may also help to explain the longevity of some of the centres because whilst it would be easy to knock-them down and replace the buildings, it would be difficult to recreate the social and cultural environments which they contain Finally, the data presented here shows that the development of those centres as part of government policy has had many of the desired effects. It has brought not just the retail space close to where people live but has also spread International and Regional brands out across the Island.

It was expected that International and Regional brands would prefer to open in Managed centres and on Orchard Road or elsewhere in the Central Area. The similarity matrices showed that the picture is rather more complicated. These brands definitely tend to avoid opening in Strata centres but they have a significant preference for MRT centres over other Managed centres. It would seem that there is more of a distinction between the mass-market International (McDonalds, GNC, Levis) and Regional brands (AS Watson, City Chain, Face Shop) which can be found in many shopping centres, and the luxury or specialist International 
brands which tend to cluster in the Orchard and Downtown areas. The latter may cater to the tourist market but they also provide a reason for different types of shopping trip for local consumers. And, as destination shops, they open where they see fit, choosing shopping centres attached to hotels just as readily as some of the larger planned shopping centres.

The pro-active management style of REITs and property funds does mean that many retailers would prefer space in the Managed and MRT centres compared to the less active management of Strata centres. The former are likely to receive more improvements, better advertising and so on. However, retailers may have less say in being able to get into and then to stay in such centres. The concentration of retailers in any one portfolio in Singapore is still relatively low, thereby limiting the power of the retailers to act against the property owner. There are some multi-format retailers such as Cold Storage and NTUC FairPrice which may be able to exert more pressure but, apart from that, the most likely advantage held by many retailers is a strong retail brand that is actually desired by the managers of the centre.

What Singapore shows us is that planned shopping centres come in a wide variety of different guises, serving a wide range of needs. This relates in part to the existence of (generally) older Strata malls which have developed their own character over time, much of which depends on an eclectic mix of store types and easy entry and exit. MRT centres are more constrained because of their locations and the need to provide a particular set of store types to meet the everyday needs of local residents. The remaining Managed centres are trying to better differentiate themselves in terms of their store types and activities and it will be interesting to see if this trend continues in the near future.

\section{REFERENCES}

Competition Commission of Singapore (2008) Market Study on Retail Mall Rental Space in Singapore. Summary Study and CCS’ Views. Competition Commission of Singapore: Singapore, October. 
Credit Suisse (2011) Singapore Retail REITs. Asia Pacific/ Singapore Equity Research, $14^{\text {th }}$ March. Hong Kong: Credit Suisse.

Davies, K. (1993) 'Retailing in Singapore. Coping with change?' International Journal of Retail \& Distribution Management, 21(1), 10-20.

Fatt, J.P.T. (2001) 'Retailing in MRT malls in Singapore: Implications for entrepreneurs,' Asia Pacific Journal of Marketing and Logistics, 13(4), 19-42.

Foley, S. (1994) Shakeout, Stakeout or Breakout options for Singapore retailers and Shopping Centres. Presentation to the 1994 Singapore Retail Industry Conference, Marina Mandarin Singapore, 25-26 ${ }^{\text {th }}$ August.

Henderson, J.C., Chee, L., Mun, C.N. and Lee, C. (2011) 'Shopping, tourism and retailing in Singapore,' Managing Leisure, 16 (1), 36-48.

Ibrahim, M.F. and Peng, L.F. (2005) The development of Neighbourhood centres in Singapore: From Traditional to Cluster Shopping,' Pacific Rim Property Research Journal, 11 (4), 373-392.

Sim, L.L. (1984) A Study of Planned Shopping Centres in Singapore. Singapore University Press: Singapore.

Sim, L.L. (1999) 'Restructuring the small scale retail sector in Singapore,' International Journal of Retail and Distribution Management, 27 (2), 83-90.

Sim, L.L. and Choo, S. (eds) (1993) The Changing Face of Retail Development and Planning in Singapore. SNP Publishers: Singapore

Sim, L.L. and Goh, S.Y. (1998) 'Singapore's revised concept plan and retailing: impact of the Tampines regional centre on shopping patterns', Journal of Retailing and Consumer Services, 5 (1), 33-43.

Sim, L-L., Yu, S-M. And Malone-Lee, L-C. (2002) 'Re-examining the retail hierarchy in Singapore. Are the town centres and neighbourhood centres sustainable?' Town Planning Review, 73 (1), 63-81.

West, D.S. (1992) ‘An Empirical Analysis of Retail Chains and Shopping Center Similarity,' The Journal of Industrial Economics, 40 (2), 201-221.

White, J.R. and Gray, K.D. (1996) Shopping Centers and Other Retail Properties. Investment, Development, Financing and Management. John Wiley: New York.

Whiting, D. (2007) Playing the REITs Game: Asia's New REITS. Singapore, John Wiley (Asia)

Yeung, Y.M. and Yeh, S.H.K. (1971) 'Commercial Patterns in Singapore's Public Housing Estates,' Journal of Tropical Geography, 23, 73-86. 
Table 1 : A Classification of Shopping Centres in Singapore

\begin{tabular}{|c|c|c|c|c|c|}
\hline $\begin{array}{l}\text { Type of } \\
\text { Centre }\end{array}$ & Concept & Size (m2) & Anchor & $\begin{array}{l}\text { Type of } \\
\text { Anchor }\end{array}$ & Location \\
\hline Regional malls & $\begin{array}{l}\text { General } \\
\text { merchandise, } \\
\text { fashion }\end{array}$ & $\begin{array}{l}\text { Over } \\
37,000\end{array}$ & 2 or more & $\begin{array}{l}\text { Department } \\
\text { store, } \\
\text { supermarket, } \\
\text { electronics, } \\
\text { furniture, } \\
\text { books }\end{array}$ & $\begin{array}{l}\text { No specific } \\
\text { locations }\end{array}$ \\
\hline City Malls & $\begin{array}{l}\text { General } \\
\text { merchandise, } \\
\text { fashion }\end{array}$ & $\begin{array}{l}9,000- \\
28,000\end{array}$ & $\begin{array}{l}\text { Not } \\
\text { necessary }\end{array}$ & & $\begin{array}{l}\text { Central Area e.g. } \\
\text { Raffles Place, } \\
\text { Orchard and } \\
\text { Marina Areas }\end{array}$ \\
\hline $\begin{array}{l}\text { Suburban } \\
\text { Malls }\end{array}$ & $\begin{array}{l}\text { General } \\
\text { merchandise, } \\
\text { fashion, } \\
\text { convenience } \\
\text { shopping }\end{array}$ & $\begin{array}{l}9,000- \\
37,000\end{array}$ & 1 or more & $\begin{array}{l}\text { Department } \\
\text { store, } \\
\text { supermarket, } \\
\text { electronics, } \\
\text { furniture, } \\
\text { books }\end{array}$ & Suburban Areas \\
\hline Neighbourhood & $\begin{array}{l}\text { General } \\
\text { merchandise, } \\
\text { convenience } \\
\text { shopping }\end{array}$ & $\begin{array}{l}1,000- \\
14,000\end{array}$ & N.A. & N.A. & $\begin{array}{l}\text { Neighbourhood } \\
\text { areas }\end{array}$ \\
\hline Specialty Malls & $\begin{array}{l}\text { Specialty } \\
\text { merchandise } \\
\text { e.g. } \\
\text { electronics, } \\
\text { higher-end } \\
\text { merchandise, } \\
\text { fashion }\end{array}$ & $\begin{array}{l}4,600- \\
23,000\end{array}$ & N.A. & N.A. & $\begin{array}{l}\text { No specific } \\
\text { location }\end{array}$ \\
\hline Entertainment & $\begin{array}{l}\text { Entertainment } \\
\text { outlets }\end{array}$ & N.A. & N.A. & N.A. & N.A. \\
\hline $\begin{array}{l}\text { Warehouse } \\
\text { Retail Scheme/ } \\
\text { Standalone }\end{array}$ & $\begin{array}{l}\text { Electronics, } \\
\text { supermarkets, } \\
\text { furniture }\end{array}$ & N.A. & N.A. & N.A. & Tampines \\
\hline Others & N.A. & N.A. & N.A. & N.A. & N.A. \\
\hline
\end{tabular}

Source: Competition Commission of Singapore (2008) 
Table 2 : Product Areas and Categories used in the Survey

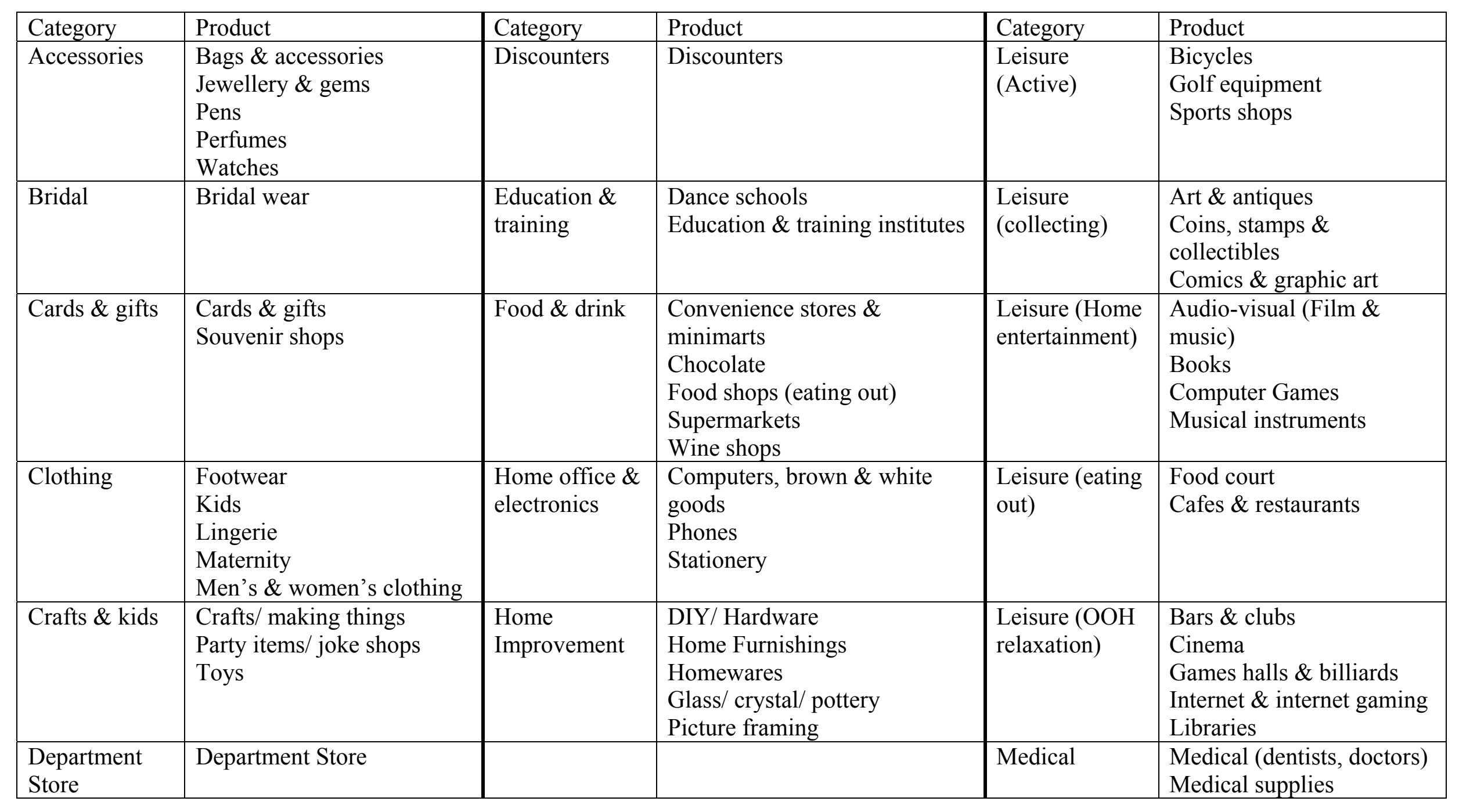


Table 2 : Product Areas and Categories used in the Survey (continued)

\begin{tabular}{|l|l|l|l|l|l|}
\hline Category & Product & Category & Product & Category & Product \\
\hline MRT & $\begin{array}{l}\text { Attached to/ immediate access } \\
\text { from an MRT station }\end{array}$ & Second Hand & Second hand shops & $\begin{array}{l}\text { Sewing \& } \\
\text { tailoring }\end{array}$ & $\begin{array}{l}\text { Sewing materials \& textiles } \\
\text { Tailors \& textiles }\end{array}$ \\
\hline $\begin{array}{l}\text { Office \& } \\
\text { stationery } \\
\text { supplies }\end{array}$ & $\begin{array}{l}\text { Office (including maid } \\
\text { services) } \\
\text { Office supplies }\end{array}$ & Services & $\begin{array}{l}\text { Automobile products } \\
\text { Florists } \\
\text { Key cutters \& shoe repairs } \\
\text { Laundry services } \\
\text { Newsagents } \\
\text { Photo processing }\end{array}$ & $\begin{array}{l}\text { Spirituality } \\
\text { Religious items }\end{array}$ \\
\hline $\begin{array}{l}\text { Personal care/ } \\
\text { wellbeing }\end{array}$ & $\begin{array}{l}\text { Cosmetics \& personal care } \\
\text { items } \\
\text { Health products } \\
\text { Pharmacies \& Chinese } \\
\text { medicine } \\
\text { Spectacles \& sunglasses }\end{array}$ & $\begin{array}{l}\text { Services } \\
\text { (Financial) }\end{array}$ & $\begin{array}{l}\text { Monks } \\
\text { offices } \\
\text { Post Offices } \\
\text { Singapore Pools }\end{array}$ & Travel & $\begin{array}{l}\text { Luggage } \\
\text { Travel agents }\end{array}$ \\
\hline Pets & $\begin{array}{l}\text { Pet shops } \\
\text { (Pervices }\end{array}$ & $\begin{array}{l}\text { Adult \& sex shops } \\
\text { Beauty salons, hairdressers \& } \\
\text { massage } \\
\text { Tattoo parlours } \\
\text { Wig shops }\end{array}$ & Void & Empty units \\
\end{tabular}


Table 3 : Number of units by shopping centre management style

\begin{tabular}{|l|c|r|r|r|r|}
\hline & Number of & \multicolumn{4}{|c|}{ Number of units } \\
\cline { 5 - 7 } & retailers & \multicolumn{1}{c|}{ Total } & \multicolumn{1}{c|}{ MRT } & Managed & \multicolumn{1}{c|}{ Strata } \\
\hline International brands & 239 & 980 & 507 & 426 & 47 \\
\hline Regional brands & 102 & 705 & 436 & 227 & 42 \\
\hline Singaporean brands & 240 & 1319 & 868 & 367 & 84 \\
\hline Independents & 7172 & 7072 & 1979 & 1856 & 3237 \\
\hline Other non-retail & & 2493 & 531 & 719 & 1243 \\
\hline Empty units & & 424 & 112 & 173 & 139 \\
\hline Total units & & $\mathbf{1 2 9 9 3}$ & $\mathbf{4 4 3 3}$ & $\mathbf{3 7 6 8}$ & $\mathbf{4 7 9 2}$ \\
\hline
\end{tabular}

Table 4 : Number of units by planning region

\begin{tabular}{|l|r|r|r|r|r|r|r|}
\hline & \multirow{2}{*}{$\begin{array}{c}\text { No. of } \\
\text { retailers }\end{array}$} & \multicolumn{7}{|c|}{ Number of units } \\
\cline { 3 - 8 } & & Total & Orchard & $\begin{array}{c}\text { Downtown } \\
\text { Core }\end{array}$ & $\begin{array}{c}\text { Rest of } \\
\text { Central } \\
\text { Area }\end{array}$ & Fringe & OCR \\
\hline International brands & 239 & 980 & 302 & 181 & 62 & 206 & 229 \\
\hline Regional brands & 102 & 705 & 136 & 92 & 56 & 160 & 261 \\
\hline Singaporean brands & 240 & 1319 & 217 & 167 & 84 & 288 & 563 \\
\hline Independents & 7143 & 7072 & 1773 & 1137 & 1929 & 1088 & 1145 \\
\hline Other non-retail & & 2493 & 858 & 307 & 648 & 322 & 358 \\
\hline Empty units & & 424 & 92 & 17 & 224 & 56 & 35 \\
\hline Total units & & $\mathbf{1 2 9 9 3}$ & $\mathbf{3 3 7 8}$ & $\mathbf{1 9 0 1}$ & $\mathbf{3 0 0 3}$ & $\mathbf{2 1 2 0}$ & $\mathbf{2 5 9 1}$ \\
\hline
\end{tabular}


Table 5: Similarity of Store Types by Type of Management

\begin{tabular}{|l|c|c|}
\hline & \multicolumn{2}{|c|}{ Similarity Index $\mathbf{S}_{\mathbf{i j}}$} \\
\hline & Average & $\begin{array}{c}\text { Standard } \\
\text { deviation }\end{array}$ \\
\hline Managed centres & 0.378 & 0.213 \\
\hline MRT centres & 0.720 & 0.096 \\
\hline Strata centres & 0.367 & 0.200 \\
\hline & & 0.211 \\
\hline Managed centres x MRT centres* & 0.467 & 0.179 \\
\hline Managed centres x Strata centres* & 0.345 & 0.174 \\
\hline MRT centres x Strata centres* & 0.418 & \\
\hline
\end{tabular}

* Note: The symbol ' $\mathrm{x}$ ' means that one set of centres is being compared with another set of centres, but comparisons within each set are excluded.

Table 6: Similarity of Store Types by Location

\begin{tabular}{|l|c|c|}
\hline & \multicolumn{2}{|c|}{ Similarity Index $\mathbf{S}_{\mathbf{i j}}$} \\
\hline & Average & Standard deviation \\
\hline Orchard Road & 0.348 & 0.188 \\
\hline Downtown Core & 0.600 & 0.093 \\
\hline Rest of Central Area & 0.333 & 0.217 \\
\hline Fringe & 0.680 & 0.101 \\
\hline Outside Central Area (OCR) & 0.645 & 0.177 \\
\hline & & \\
\hline Orchard Road x Downtown Core & 0.422 & 0.184 \\
\hline Orchard Road x Rest of Central Area & 0.331 & 0.196 \\
\hline Orchard Road x Fringe & 0.417 & 0.195 \\
\hline Orchard Road x OCR & 0.407 & 0.186 \\
\hline Downtown Core x Rest of Central Area & 0.414 & 0.192 \\
\hline Downtown Core x Fringe & 0.632 & 0.118 \\
\hline Downtown Core x OCR & 0.594 & 0.146 \\
\hline Rest of Central Area x Fringe & 0.415 & 0.201 \\
\hline Rest of Central Area x OCR & 0.395 & 0.196 \\
\hline Fringe x OCR & 0.666 & 0.148 \\
\hline
\end{tabular}

* Note: The symbol ' $\mathrm{x}$ ' means that one set of centres is being compared with another set of centres, but comparisons within each set are excluded. 
Table 7: Origin of retail brands across selected product areas: number of units

\begin{tabular}{|c|c|c|c|c|}
\hline & $\begin{array}{l}\text { International } \\
\text { Brands }\end{array}$ & Regional Brands & $\begin{array}{l}\text { Singaporean } \\
\text { Brands }\end{array}$ & TOTAL \\
\hline Audio-Visual & 2 & 3 & 68 & 73 \\
\hline Bags/ Accessories & 36 & 21 & 24 & 81 \\
\hline Beauty/ Hair & - & 8 & 16 & 24 \\
\hline Books & 2 & 3 & 42 & 47 \\
\hline Cards/ gifts & 19 & - & 10 & 29 \\
\hline Clothing & 218 & 197 & 128 & 543 \\
\hline Collectibles/ comics & - & - & 29 & 29 \\
\hline Cosmetics & 63 & 36 & 12 & 111 \\
\hline Convenience Stores & - & 35 & 11 & 46 \\
\hline Department Stores & - & 6 & 22 & 28 \\
\hline DIY & - & - & 21 & 21 \\
\hline Electronics & 19 & 20 & 24 & 63 \\
\hline Food & 26 & 19 & 137 & 182 \\
\hline Health & 39 & 7 & 70 & 116 \\
\hline Home Furnishings & - & 15 & 27 & 42 \\
\hline Jewellery & 6 & 8 & 138 & 152 \\
\hline Kids & 33 & 16 & 26 & 75 \\
\hline Mobile phones & 27 & 7 & 74 & 108 \\
\hline Optical/ spectacles & 2 & 23 & 63 & 88 \\
\hline Pharmacy & - & 89 & 39 & 128 \\
\hline Restaurants & 219 & 56 & 102 & 377 \\
\hline Shoes & 95 & 18 & 53 & 166 \\
\hline Sports & 70 & 2 & 52 & 124 \\
\hline Supermarkets & 2 & 34 & 14 & 50 \\
\hline Toys & 12 & 2 & 15 & 29 \\
\hline Watches & 26 & 38 & 40 & 104 \\
\hline TOTALS & 932 & 669 & 1269 & 2870 \\
\hline
\end{tabular}


Table 8: Similarity of Retail Brand Origin by Type of Management

\begin{tabular}{|c|c|c|c|c|c|c|c|c|}
\hline & \multicolumn{8}{|c|}{ Retail Brand Origin } \\
\hline & \multicolumn{2}{|c|}{ International } & \multicolumn{2}{|c|}{ Regional } & \multicolumn{2}{|c|}{ Singaporean chains } & \multicolumn{2}{|c|}{ Independents } \\
\hline MRT centres & 0.652 & 0.144 & 0.657 & 0.241 & 0.717 & 0.245 & 0.831 & 0.070 \\
\hline Strata centres & 0.156 & 0.328 & 0.161 & 0.332 & 0.223 & 0.317 & 0.642 & 0.209 \\
\hline $\begin{array}{l}\text { Managed centres X } \\
\text { Strata centres* }\end{array}$ & 0.235 & 0.357 & 0.247 & 0.358 & 0.305 & 0.352 & 0.600 & 0.257 \\
\hline $\begin{array}{l}\text { MRT centres } \mathrm{x} \\
\text { Strata centres* }\end{array}$ & 0.341 & 0.359 & 0.383 & 0.387 & 0.458 & 0.270 & 0.727 & 0.389 \\
\hline
\end{tabular}


Table 9: Similarity of Retail Brand Origin by Type of Management and Location

\begin{tabular}{|c|c|c|c|c|c|c|c|c|}
\hline & \multicolumn{8}{|c|}{ Retail Brand Origin } \\
\hline & \multicolumn{2}{|c|}{ International } & \multicolumn{2}{|c|}{ Regional } & \multicolumn{2}{|c|}{ Singaporean chains } & \multicolumn{2}{|c|}{ Independents } \\
\hline & mean & std dev. & mean & std dev. & mean & std dev. & mean & std dev. \\
\hline \multicolumn{9}{|l|}{ Managed centres: } \\
\hline Orchard Road & 0.371 & 0.254 & 0.323 & 0.374 & 0.349 & 0.260 & 0.555 & 0.267 \\
\hline Downtown Core & 0.396 & 0.348 & 0.469 & 0.252 & 0.549 & 0.559 & 0.864 & 0.043 \\
\hline Rest of Central Area & 0.153 & 0.264 & 0.107 & 0.243 & 0.267 & 0.551 & 0.419 & 0.293 \\
\hline Fringe & 0.570 & n.a & 0.670 & n.a & 0.880 & n.a. & 0.810 & n.a. \\
\hline OCR & 0.470 & 0.284 & 0.555 & 0.276 & 0.169 & 0.158 & 0.813 & 0.061 \\
\hline \multicolumn{9}{|l|}{ MRT centres: } \\
\hline Orchard Road & 0.710 & n.a. & 0.670 & n.a. & 0.670 & n.a. & 0.740 & n.a. \\
\hline Downtown Core & 0.697 & 0.046 & 0.670 & 0.289 & 0.707. & 0.192 & 0.771 & 0.036 \\
\hline Rest of Central Area & 0.550 & n.a. & 0.910 & n.a. & 0.670 & n.a. & 0.850 & n.a. \\
\hline Fringe & 0.552 & 0.194 & 0.660 & 0.252 & 0.686 & 0.192 & 0.841 & 0.070 \\
\hline OCR & 0.677 & 0.118 & 0.654 & 0.240 & 0.717 & 0.250 & 0.831 & 0.071 \\
\hline \multicolumn{9}{|l|}{ Strata centres: } \\
\hline Orchard Road & 0.225 & 0.373 & 0.140 & 0.305 & 0.165 & 0.209 & 0.633 & 0.145 \\
\hline Downtown Core & 0.000 & n.a. & 0.000 & n.a. & 0.400 & n.a. & 0.880 & n.a. \\
\hline Rest of Central Area & 0.041 & 0.189 & 0.024 & 0.387 & 0.370 & 0.357 & 0.667 & 0.254 \\
\hline Fringe & n.a & n.a & n.a & n.a & 0.670 & n.a. & 0.900 & n.a. \\
\hline OCR & n.a. & n.a & n.a. & n.a. & n.a. & n.a. & n.a. & n.a. \\
\hline
\end{tabular}

